\title{
Public-Private-Partnership (Ppp) in Nigeria
}

\author{
Theresa U Akpoghome* \\ Theophilus Chinedu Nwano*
}

\section{A. Abstract}

Public-Private-Partnership (PPP) in Nigeria is a major issue of discourse among individuals, corporate bodies and government. PPP is a tool to deliver the much needed infrastructural services. Building modern, sustainable and reliable infrastructure is critical for meeting the rising aspirations of millions of people in Nigeria and PPP helps to raise economic growth rates, offers new economic opportunities and facilitates investment in human capital. This paper examines the historical background and types of Public-Private-Partnership in Nigeria. It discovers that the problems or the challenges of Public-Private-Partnership include multiplicity of functions by various bodies, definitional issues, joint venture agreements, conflicts and contractual review conflicts. The paper discovers that one of the major challenge in PPP agreements is the absence of arbitration clause in the contracts. The paper recommends that the insertion of arbitration clause should be encouraged to reduce incidences of prolonged litigation. Synergy among regulatory bodies is also recommended to foster reduction in the issue of double taxation and encourage more private investment participation. The paper concludes that Public-Private-Partnership remains one of the most important developmental avenues available to the government to revive the decaying public corporations, utilities and public goods and services of global standards through cost effective mechanisms.

KEY WORDS: Public-Private-Partnership; Nigeria; Joint Ventures; Privatization

\section{Introduction}

The provision of services and infrastructural facilities are the most important functions of every government in relation to developmental achievements of a nation. The involvement of the private sector in the development and financing of public facilities and services has increased over the past years in the developed and developing countries. ${ }^{1}$

* Akpoghome, Theresa U, PhD, LL.M, LL.B, BL., Professor, Department of Public Law, Faculty of Law, Benson Idahosa University, Benin City, Edo State, Nigeria. E-Mail: teremajor@gmail.com, takpoghome@biu.edu.ng. Ph: +2348065436545,+2348056317472.

* Nwano T. C. PhD, LL.M, LL.B, BL., Lecturer, Department of Public Law, Faculty of Law, Benson Idahosa University, Benin City, Edo State, Nigeria. E-Mail: tnwano@gmail.com, tnwano@biu.edu. ng. Ph: +2348033372420 .

1 Ndukwe, C., and Nwuzor, C., "PPP for Effective and Efficient Services Delivery in Nigeria: A Study of Ebonyi State"; Public Policy and Administrative Research. (2016) Vol. 6. No 5. 
It is undoubted that the provision of certain basic services are undertaken by the public sector in Nigeria, such provision is lacking in quantity and quality of services required for sustainable development principally due to shortage of public funds, embezzlements and the monumental corruption surrounding the implementation of approved funds by public officers.

Public-Private-Partnership (PPP) came into being when government began to explore more subtle alternatives for accessing private sector resources in delivery and operation of public facilities. It also arose as a medium for service development i.e. to make available adequate welfare services through public and private sectors arrangements. ${ }^{2}$ PPP is one of the numbers of ways of delivering public infrastructure, facilities and related services. ${ }^{3}$ It is not a substitute for strong and effective governance and decision making by government. In all cases, government remains responsible and accountable for delivery of services and project in a manner that protects and furthers the public interest. In view of the above, this paper is divided into eight parts. Part I introduces the paper and Part II deals with conceptual definitions. Part III discusses the historical background of Public-Private-Partnership (PPP) with particular reference to Nigeria. Part IV discusses types Public-Private-Partnership (PPP). Part V discusses the legal framework for Public-Private-Partnership (PPP) while Part VI discusses the challenges of PPP. Part VII proffers solution to the challenges and Part VIII concludes the paper.

\section{Conceptual Definitions}

The Organisation for Economic Development and Cooperation (OECD) defines a publicprivate partnership as an agreement between the government and one or more private partners (which may include the operators and the financers) according to which the private partners deliver the service in such a manner that the service delivery objectives of the government are aligned with the profit objectives of the private partners and where the effectiveness of the alignment depends on a sufficient transfer of risk to the private partners. ${ }^{4}$

The Asian Development Bank (ADB) appears to have the most comprehensive definition and seems to sum up all the characteristics that have been pointed out in the previous definition. According to the Asian Development Bank, Public-private partnership describes a range of possible relationships among public and private entities in the context of infrastructure and other services. PPPs present a framework that while engaging the private sector in public project the contract must acknowledge and structure the role for government in ensuring that social obligations are met and successful sector reforms and public investments achieved. A strong PPP allocates the tasks, obligations, and risks among the public

2 Ibid.

3 Ibid.

4 Jose, L. N. and Jose, A. M. 'Public Private Partnerships and Regional Productivity in the United Kingdom', http://www.reser.net/file/75439/ (Last accessed $2^{\text {nd }} J u l y, 2019$ ). 
and private partners in an optimal way. The public partners in a PPP are government entities, including ministries, departments, municipalities, or state-owned enterprises. The private partners can be local or international and may include businesses or investors with technical or financial expertise relevant to the project. Increasingly, PPPs may also include non-governmental organizations (NGOs) and/or community-based organizations (CBOs) that represent stakeholders directly affected by the project. Effective PPPs recognize that the public and the private sectors each have certain advantages, relative to the other, in performing specific tasks. The government's contribution to a PPP may take the form of capital for investment (available through tax revenue), a transfer of assets, or other commitments or in-kind contributions that support the partnership.

The government also provides social responsibility, environmental awareness, local knowledge, and an ability to mobilize political support. The private sector's role in the partnership is to make use of its expertise in commerce, management, operations, and innovation to run the business efficiently. The private partner may also contribute investment capital depending on the form of contract". 5

PPP is the collaboration between the public and private sector to provide infrastructure which used to be traditionally an exclusive role for the public authority. ${ }^{6}$

It can be seen from the above discussions that there are various definitions of what constitutes a PPP arrangement. However, there are certain baseline characteristics that tie these different definitions together. Some of these characteristics have been highlighted from the definitions above. The Malaysian PPP Guidelines lists them as:

i. The relationship between the public and private sectors is based on a partnership, which means that risk is shared between both partners optimally as it is allocated to the party who is best able to manage it;

ii. The public sector procures specified outputs and outcomes of a service for the contract period whilst the private sector determines the required inputs to achieve the specified output. The private sector is given the freedom to introduce innovation into their design and development to reduce cost; there is thus an integration of design, construction, finance and maintenance and operation;

iii. Payment for services is based on predetermined standards and performances;

iv. PPP promotes a 'maintenance culture' where the private sector will be responsible for the long term maintenance of the assets throughout the operational period agreed upon by the parties;

5 Asian Development Bank, 'Using Innovative Policy and Regulatory Approaches for Sustainable Development', $<$ http://www.org.au/docs/ADB\%20Public\%20Private\%20Partnership\%20Handbook pdf $>$ (Last accessed $2^{\text {nd }}$ July, 2019).

6 Augustine, E.A., "An Appraisal of the Framework for Public Private Partnership in South Africa", European Journal of Procurement and Public Partnership Law Review (2018), Vol. 13, No. 3, p 1. 
v. In some instances, there is an option for the transfer of the infrastructure asset back to the public sector at the end of the contract period;

vi. PPP involves a Whole Life Cycle Costing ("WLCC") whereby PPP projects are usually awarded based on lowest total cost over the contract period compared to lowest construction cost under traditional procurement. ${ }^{7}$

Majority of projects that are classified as PPPs will have a number of these characteristics. Importantly however, the partnership structure must allocate risks and rewards optimally amongst the public and private parties in accordance with the strengths and abilities of each of the parties. It is only this optimal allocation of risks and benefits that ensures that each party contributes in an effective manner to the project.

\section{The Historical Background of Public-Private-Partnership (PPP)}

The modern concept of PPPs is commonly said to have originated in the United Kingdom. ${ }^{8}$ However, the concept that emerged in the United Kingdom is similar to the model used to facilitate independent power projects in the United States of America in the 1980s. Thus while it can be said that the emergence of modern forms of PPPs may be traced to the Private Finance Initiative (PFI) scheme of the United Kingdom that was launched in 1992, the template for modern PPP contracts may be traced to Power Purchase Agreements (PPAs) signed by the US authorities and independent power producers in the 1980s. ${ }^{9}$

Even though the modern concept of PPP is relatively new, the idea of toll roads and bridges are not. For example, in the United Kingdom and the United States of America as far back as the eighteenth and nineteenth centuries over 2500 companies were chartered and incorporated to develop private turnpikes. ${ }^{10}$ These turnpikes basically involved local business entrepreneurs forming trusts, which borrowed money from private investors to repair roads and repaid them by charging tolls. For instance, in the 19th century the Brooklyn Bridge in New York was built with private sector capital. ${ }^{11}$ Also as far back as the seventeenth century, French concession models were employed to develop infrastructure, especially in sectors such as water. ${ }^{12} \mathrm{~A}$ further development in the use of the concession model

7 Malaysian Public Private Guidelines (2009) PPP Unit, Prime Ministers Department Putrajaya http://www.ukas.gov.my/html/themes/miu/content/rn bi 131109.pdf (Last accessed on $29^{\text {th }}$ February, 2019).

8 Yescombe, E.R. 'Public-Private Partnerships: Principles of Policy and Finance', (Massachusetts, 2007) p. 9.

9 Ibid.

10 Takim, R. et all, 'A Value for Money Assessment Method for Public Private Partnership: A Lesson from Malaysian Approach', International Conference on Economics and Finance Research Singapore (IPEDR), Vol. $14 \mathrm{http}: / /$ www.ipedr.com/vol4/101-F10145.pdf (Last accessed on $28^{\text {th }}$ June, 2019).

11 Ibid.

12 Ibid. 
in France was the use of franchises which basically is the right given to the private sector to exploit an already existing asset by making lump sum payments to the public sector. ${ }^{13}$ The use of these methods faded away after the 19th century as the role of the State in the provision of infrastructure expanded. ${ }^{14}$

More recently, PPPs have become a global phenomenon. Sectors in which PPPs have been completed worldwide, include: Electric power generation and distribution, water and sanitation, refuse disposal, healthcare, education, airports facilities, prisons, transportation (railways, roads) technology systems, and housing etc.

Since the beginning of the fourth democratic experience in May 1999, the Federal Government of Nigeria has embarked on an extensive liberalization and privatization program to inject private sector money and expertise in order to ensure quality infrastructure service delivery to the teeming population. ${ }^{15}$ The assumption is that private sector investment in infrastructure is a key priority in moving Nigeria to the status of top 20 economies in the world. ${ }^{16}$

However, over the years, at the central level, the government has taken serious steps in pursuit of its infrastructure targets. In 2007 specifically, the Federal Government of Nigeria articulated its Seven Point Agenda which outlined the seven key drivers for Nigerian development. ${ }^{17}$ At the top of this list of indicative parameters, is the adequate provision of critical infrastructure ${ }^{18}$ as a means to catalyze economic growth with the transport sector as a high priority for PPP investment. ${ }^{19}$ At the level of the states, the national infrastructure strategy has been endorsed and a commitment has been made towards the agenda for countrywide infrastructure development.

13 Ibid.

14 Yescombe, note 14 at p.5.

15 Conference on Infrastructure Development in Nigeria, Report of the Nigerian Economic Summit Group International PPP and infrastructure development in Nigeria (2004) p1.

16 Ibid.

17 Project Appraisal Document 46. https://www.google.com/search?client=firefox-b-d\&q=Project+A ppraisal+Document+46. (Last accessed on $15^{\text {th }}$ July, 2019).

18 The critical infrastructure include: Power, transportation, national gas distribution and telecommunications. For electricity - to develop an integrated, lowest cost, expansion plan for the development of the Nigerian electricity industry in the medium and long-term; upgrade and reinforce distribution network; develop appropriate gas policy to encourage production and supply of gas for electricity generation; develop gas production and supply infrastructure; and develop a policy on IPPs. For transport - provide platforms for PPP, with capacity building in MDAs. For roads - explore mechanisms to ensure funding for maintenance investments. For railways - revive the system and involve the private sector. For aviation - the priority is to establish the National Civil Aviation Authority as the cornerstone of reform, including a recertification project.

19 Project Appraisal Document. Others are: the Niger Delta region; food security; human capital; land tenure changes and home ownership; national security; and wealth creation. 
Pursuant to the above, the Federal Government inaugurated the Infrastructure Concession Regulatory Commission (Commission) ${ }^{20}$ in late 2008 to drive the program in Nigeria. As a first step towards establishing the proper legal and regulatory environment to attract private sector investors, the Federal Executive Council approved the National Policy on Public Private Partnership, sponsored by the Commission after stakeholder consultations and technical inputs from, inter alia, the World Bank and the United Kingdom Department for International Development (DFID). The key PPP principles driven by the Commission are: value for money; public interest; output requirements; transparency; risk allocation; competition; and capacity to deliver.

This policy sets forth the ways in which private investment could be leveraged in tackling the menace of poor infrastructure stocks and boosting delivery of services to the public in a manner that is sustainable. This is pursuant to sections 33 and 34 of the Infrastructure Concession Regulatory Commission Act (ICRCA) which empower the Commission to take directives from the President regarding matters of policy and power to make regulations, respectively. ${ }^{21}$ There are economic, social and environmental objectives for the adoption of PPP model as a strategy for infrastructure development. ${ }^{22}$ It is the belief of the government that a private-sector led drive for infrastructure development through PPPs will open up the infrastructure and service delivery landscape in Nigeria to efficiency, inclusive access and overall improvement of the quality of public service delivery in a sustainable way. ${ }^{23}$ In pursuit of this lofty agenda, they came up with a supposed more investor-friendly legal and regulatory environment so that the provision of infrastructure assets and delivery of services to the public could be private-sector driven.

The Infrastructure Concession Regulatory Commission Act (ICRCA) stands as the closest legislation in Nigeria that can easily be referred to as the infrastructure law. The apparent successes that came in the way of provision of telephone services and the global system of mobile telecommunication (GSM) really heightened the expectation that the private sector participation is a sure-footed path to better service delivery and procurement of highgrade and cost-effective public infrastructure stocks. ${ }^{24}$

20 Established by section 14 of Infrastructure Concession Regulatory Commission Act (ICRCA), to regulate, monitor and supervise the contracts for infrastructure or development projects.

21 The World Bank (2011) Project Appraisal Document 6. https://www.google.com/search?client=fir efox-b-d\&q=Project+Appraisal+Document+46. (Last accessed on $15^{\text {th }}$ July, 2019).

22 The Infrastructure Concession Regulatory Commission (ICRC) National Policy on PPP (2009) p1012.

23 Ibid.

24 Investments in telecommunications industry grew from US million in 2000 to US billion in 2010. See Ahmed, 'PPP for Infrastructure Development: The Nigerian Experience', as cited by Solomon, O.B., et-all in Challenges in Implementing Public Private Partnership strategy For Infrastructure Delivery In Nigeria, Faculty of Engineering and Environment, Northumbria University, Newcastle upon Tyne, NE1 8ST, UK http://nrl.northumbria.ac.uk/17191/3/babatunde_et_al_ppp_conference_ paper_\%25281\%2529_\%281\%29.pdf. (Last accessed on $15^{\text {th }}$ July, 2019). 
In Nigeria, the bad state of infrastructure and the willingness of the government to restore such infrastructure with little or no funds necessitated the drive for PPP, more so the failure and the inefficiency of public authorities in providing and maintaining the desired infrastructure for the Nigerian populace, bred the influx of private sector investment in Nigeria. The decision to resort to PPP was made easier by the fact that the country had gone through a privatization program that lasted for over 3 decades. This also included a reform program encompassing the liberalization and deregulation of the economy. ${ }^{25}$ In essence, there was a partial liberalized economic environment in place; PPP was thus seen as the natural progression from privatization. Also, unlike the privatization program, complete transfer of ownership of assets from the Government to the private sector is not an attribute of PPP and so people were naturally more comfortable with it.

Nigeria being a developing country, with a moderate capital budget, an undeveloped capital market and not very buoyant private sector had to rely on foreign private sector funding to realize its goals of providing infrastructure for its citizens. It is not surprising therefore that most of the early investments in infrastructure via PPP came through collaboration between foreign investors and Nigerian businesses. The multilateral financial agencies also came in with a lot of support and finance. ${ }^{26}$

Some of the transactions that have been consummated so far are mainly in the transport sector including a MM2 airport terminal in Lagos, a new toll road in the Lekki area of Lagos, the seaports located around Lagos and the Niger Delta Region of the country. It is clear therefore from the foregoing that Nigeria has fully embraced the use of PPP to finance infrastructure. However, due to the desperation and haste by government to provide infrastructure, crucial enablers to ensure for successful PPP transactions were never put in place leading to economic inefficient litigations as exemplified in the case of BFI Group Corporation v. B.P.E. ${ }^{27}$ The issue in this case was whether on a proper evaluation of both oral and documentary evidence adduced before the trial court, the Court of Appeal was right in affirming the finding of fact by the trial court that there was no contract between the parties that was capable of being enforced by an order of specific performance. The fact was that the respondent advertised for expression of interest by interested bidders for the privatization of the Aluminum Smelter Company of Nigeria (ALSCON). The appellant completed the request for proposals (RFP) issued by the National Council on privatization (NCP). The said RFP completed by the appellant was tendered in evidence at the trial court as "exhibit DI". Therein, it was confirmed that a bidder would be selected on the basis of evaluation and selection procedure approved by the NCP and contained in the RFP. By the last provision of exhibit DI, the appellant was made to subscribe to a memorandum of acceptance by which

25 This program was pursed through the Bureau of Private Enterprise (BPE). Under this program over 200 transactions were concluded.

26 On $21^{\text {st }}$ September, 2017 the World Bank group help Nigerian government design public private partnership and create a balanced regulatory environment to ensure a more efficient and sustainable provision of public services and infrastructure.

27 (2012) 18 NWLR (Pt. 1332) p209. 
it attested to and sealed the terms of the contract by its seal duly signed by one of its Directors and Secretary.

In tune with exhibit DI, a pre-bid conference was held on 20th May 2004. At the conference, a number of undertakings and Agreement were reached is furtherance of the sale of ALSCON. At the end of the pre-bid conference, the undertakings and agreements were set down by the respondent and addressed to the appellant. This was "exhibit 3". The appellant affirmed and returned a duplicate copy of the undertakings agreements (exhibit 5) to the respondent. In compliance with the duplicate, the appellant caused a bid bond in the form prescribed by the respondent to be issued to secure the offer. This was accepted by the respondent and the appellant was declared the preferred bidder on $14^{\text {th }}$ June, 2004. The said bid bond provided by Assurance Bank Nigeria Limited was admitted as exhibit 4 at the trial court

At the financial bid opening held on $14^{\text {th }}$ June, 2004, the appellant's bid of US $\$ 410$ million was declared the preferred bid. The second bidder, RUSAL submitted a conditional bid in the sum of US \$205 million. Its bid was disqualified. Further to the acceptance of the appellant's bid by the respondent, by its letter dated $17^{\text {th }}$ June 2006 - "exhibit 6" - confirmed same. In the said letter, the respondent introduced a unilateral condition as follows: While we wish to congratulate you on this achievement, we wish to remind you that your consortiums must pay $10 \%$ of the bid price within 15 working days of receipts of this letter".

The above was contrary to the provision of Clause (F) of exhibit 5 which states that by the standard rule of bid price payment of $10 \%$ shall be paid within 15 working days of signing the share purchase agreement. The appellant made efforts to fully consummate the sale by having the share purchase agreement signed with the visit of it officials to the office of the respondent on $8^{\text {th }}$ July, 2004. The validity period of appellant's bid was 60 days as per Clause 4.8 exhibit D. This was in addition to the fact that the bid bond was given to last for a period of six months (180 days).

On $8^{\text {th }}$ July, 2004, the respondent unilaterally extinguished the contract due to the alleged inability of the appellant to pay $10 \%$ initial bid price within 15 days of the receipt of their letter - exhibit 6 . As at the date of termination of the contract the share purchase agreement had not been signed by the parties for the purpose of computing time for the payment of the $10 \%$ initial bid price.

The appellant was aggrieved by the termination of the contract and it sued the respondent at the Federal High Court claiming a number of declaratory reliefs of specific performance. The trial court, in its judgment, found that there was no valid or enforceable contract between the parties capable of being enforced by the court. The Court of Appeal affirmed the decision of the trial court. Still aggrieved, the appellant appealed to the Supreme Court. The Supreme Court held that an order of specific performance of the contract between the parties is clearly warranted and same is hereby ordered as prayed. The appeal 
is meritorious in the extreme. It is hereby allowed. The decisions of the two courts below are hereby set aside. The claims of the appellant at the trial court are hereby granted. ${ }^{28}$

Justice Fabiyi, JSC who delivered the judgment reiterated the fact that state officials should learn to operate within the rule of law. The world has become a global village and all forms of negative tendencies must be avoided. Senior officials should operate with firmness of purpose. This must be so if we desire to be taken seriously in international trade relations.

The failure and controversy in the case above is an example of the Nigerian experience in PPPs. Nigerians had hoped that the government would have learnt some lessons from the failure of previous PPP efforts and use the concessions of MMA2 and Lagos/Ibadan highway as a model for the development of Nigeria's airports and roads infrastructure. However, there are challenges in the concession of MMA2, these include; inadequate experience of public (Ministries, Department, and Agencies that regulate PPP) and private sectors (concessionaire), political involvement at the implementation level, and inadequate project preparation. ${ }^{29}$

\section{Types of Public-Private-Partnership (PPP)}

There are different forms of Public-Private-Partnership (PPP) which are mostly depicted by different acronyms. A number of these so called different PPP arrangements are merely slight variants of one another. Some of the popular examples are:

\section{Design-Build Operate and Transfer (DBOT)}

The federal government of Nigeria in 2000 embarked on a process of reforms in aviation sector, including transferring the responsibility of the development, financing, management and operations of Nigeria airports to the private sector. In 2003, Bi-Courtney limited was awarded the concession by the federal government to develop, finance, manage and cooperate the Murtala Muhammed Airport Terminal 2 Lagos. Under a Design Build Operate Transfer (DBOT) arrangement. This was the first major DBOT project of such size in Nigeria and it marked the birth of Murtala Mohammed Airport 2 in Lagos. ${ }^{30}$

28 Ibid, p 245.

29 Solomon, O.B., et all, 'Challenges in Implementing Public Private Partnership strategy For Infrastructure Delivery In Nigeria'. Faculty of Engineering and Environment, North Umbria University, Newcastle upon Tyne, NE1 8ST, UK http://www.nrl.northumbria.ac.uk/17191/3/babatunde_et_al_ ppp_conference_paper_\%25281\%2529_\%281\%29.pdf (Last accessed on $15^{\text {th }}$ July, 2019).

30 Toyin B. and Oluwatoba O. Nigeria: Public-Private-Partnership And Road Infrastructure Development in Nigeria, Understanding The Presidential Executive Order No. 007 of 2019',

http://www.mondaq.com/Nigeria/x/790274/Government+Contracts+Procurement+PPP/PublicPriv atePartnership + And + Road + Infrastructure + Development + In + Nigeria + Understanding + The + Preside ntial+Executive + Order $+\mathrm{No}+007+$ Of +2019 (Last accessed on $23^{\text {rd }}$ June, 2019). 


\section{Build Operate and Transfer (BOT)}

This is the most popular PPP arrangement. In this type of project, the private sector entity finances the building of the infrastructure asset and is allowed to own and operate it for a number of years, usually long term before transferring control and ownership back to the public sector. These types of arrangements are common with Greenfield projects. ${ }^{31}$ The idea of a BOT is to benefit from the private sector's detailed knowledge of project design. The materials used in the construction phase can result in the development of a tailored maintenance plan over the project lifespan. ${ }^{32}$

\section{Build Own Operate (BOO)}

This PPP arrangement is similar to a BOT in the sense that the private sector finances the construction of the infrastructure and is also allowed to operate the infrastructure; however the distinguishing feature from a BOT arrangement is that the private sector is allowed to own the infrastructure in perpetuity. It is important to note that the fact that there is no government involvement in the beginning does not mean that it is not a PPP. The Government may still be involved in fixing tariffs and guaranteeing revenues. These types of arrangements are common in the power generation sector. ${ }^{33}$

\section{Build Own Operate and Transfer (BOOT)}

Under a typical BOOT, the private sector is responsible for financing the construction of the infrastructure asset. It is also allowed to own and render services deriving from that infrastructure asset for a number of years before transferring the asset to the government/public sector. $^{34}$

\section{Build Lease Transfer (BLT)}

In a BLT arrangement the private sector after building the infrastructure asset with its own funds, leases the asset from the public sector entity, paying a periodic fee before transferring the asset in the long run to the public sector at the end of the lease period. ${ }^{35}$

31 Ibid.

32 World Bank Fund < http://www.ppp.worldbank.org/public-private- partnership/agreements/conces sions-bots-dbos $>$ (Last accessed on 27th June, 2019).

33 Quinggin, J. BOOT: In the Public Interest', Presentation made at University of Technology, Sydney, March 1998 https://economics.uq.edu.au/johnquigging/conference/BOOT.html (Last accessed on 27 th June, 2019).

34 Ibid.

35 Ibid. 


\section{Build Lease Operate Transfer (BLOT)}

This is similar to the BLT but the only difference is that there is an obligation on the private sector to operate the asset for the duration of the lease before transferring the asset to the public sector entity. ${ }^{36}$

\section{Build Lease Transfer Maintain (BLTM)}

Under this arrangement, like a classic BLT, the private sector entity uses its finances to build an asset, and then leases the asset from the public sector entity, before finally transferring the asset back to the public sector. However, unlike a BLT there is an obligation on the private sector entity to continue to maintain the asset even after the transfer of the asset is completed to the public sector. ${ }^{37}$

\section{Build Transfer Operate (BTO)}

Unlike the more popular BOT transactions, in this case the asset is transferred back to the government, which now allows the private sector to operate the asset for a number of years on behalf of the government. ${ }^{38}$

\section{Own Operate Remove (BOOR)}

As the name implies, under this arrangement the private sector entity finances the construction of the infrastructure asset and owns and operates it for a number of years after which it must remove it.

\section{Design Build Finance Operate (DBFO)}

Under this scheme, the public partner specifies the services it wants the private sector to deliver. The private partner then designs and builds an asset specifically for that purpose, finances its construction and subsequently operates the asset by providing services that derive from it. ${ }^{39}$ DBFOs are considered the classic PPP projects and are indeed the most common. The Lekki Road Concession and the MMA 2 Airport terminal both in Lagos, Nigeria are all strictly speaking examples of DBFQ schemes.

36 Ibid.

37 Ibid.

38 Ibid.

39 International Monetary Fund, Public-Private Partnerships, Government Guarantees and Fiscal Risk, prepared by IMF Staff team, Washington D.C. international Monetary Fund 2006. 


\section{Design, Build, Finance, Operate, Manage (DBFOM)}

In addition to all the responsibilities and obligations of the private sector partner under a DBFO above, the private sector partner also shoulders the responsibility of managing the asset. Another variant of this is Design, Construct, Manage, and Finance (DCMF).

\section{Lease}

Leases as a form of PPP. It is usually used where the assets are already in existence and therefore it is no longer necessary to make investments in infrastructure or where the risk premium of transferring the responsibility for building of the asset to the private sector is very high.

\section{Lease Develop Operate (LDO)}

Under this scheme, the public partner take the lease of the infrastructural asset, usually empty land and then financing the development of the asset and operate such development.

\section{Lease Renovate Operate and Transfer (LROT)}

Under this arrangement there is first of all the lease of an existing asset, which is renovated and then operated by the private sector before finally transferring the asset to the public sector after a number of years.

\section{Joint Ventures}

Joint ventures are often alternatives to full privatizations in which the infrastructure is coowned and operated by both the public and private sector. In practice however, the private sector partner usually assumes the operational role. Under a joint venture both parties may decide to incorporate a joint venture company which would be responsible for the project. The major obstacle in a joint venture is drafting the joint venture agreement without envisaging dispute resolution mechanism or how to handle future or unforeseen circumstances without recourse to unnecessary delay or total breakdown or frustration of such project. Managing a joint venture is usually a complicated and complex task, especially if employees have to collaborate with counterparts in foreign jurisdictions. There are host of issues people in a joint venture can face, but many of the problems manifest themselves no matter the industry the companies are in. some of these problems include but not limited to the following: ${ }^{40}$

40 Carey T., Common Issues in Joint Ventures: https://thompsonlawtx.com/lawyer/2018/02/27/SmallBusiness/Common-Issues-in-Joint-Ventures_bl33329.htm (Last accessed on 27th June, 2019). 
i. Trying to Finish Deals Quickly: Many joint ventures run into problems once the pressure to close deals catches up with senior executives. Speed can make a big difference in cutting edge industries, but it is important for businesses to be methodical at every stage of the deal making process. Business that try to cut corners or draft up a rudimentary business plan usually face major headaches down the road once they are forced to 'catch up' due to their mistakes.

ii. Lack of Strong Leadership: Many businesses succeed in competitive industries due to a clear vision that translates into defined and stable operating procedures. Leadership problems can be tricky to navigate if those involved have little experience with joint ventures, if people have conflicts of interest, or if team members are jumping in and out of company projects at different stages. Disjointed leadership often results in priorities that are vague or uncertain, which can cause big problems once it is time to settle a deal, lead a team, or resolve a dispute in a fair manner. Good leadership is important in a joint venture to make sure that all sides are proactive with each other and are not just focusing on their own interests.

iii. Inability to Respond to Risk: Those involved in a joint venture usually steer clear of planning for each other's risk profiles due to a fear of causing conflict. Since companies in a joint venture usually have different backgrounds, experiences, and risk tolerances, it is very important to set up contingency measures and ensure there are plans in place to mitigate risk before any problems occur. Entities in a joint venture sometimes set up mechanisms like value sharing agreements or service-level agreement release valves in order to maintain stability in the face of issues as they arise. ${ }^{41}$

Types of Joint Ventures (JVs)

a. Operational Joint Ventures: this venture exist where two or more companies create a new entity that holds full complements of operating assets and capabilities necessary for developing and executing a named project.

b. Capability Sharing JV: This type of JV conducts business by leveraging a combination of capabilities from the participants. For example, one participant may bring engineering and manufacturing capabilities, while the other brings political influence and resources in certain countries. For example, the JV itself may have limited operational assets; it then coordinates a mix of capabilities held by the various participants.

c. Risk Sharing JV: Two or more companies create a JV primarily for the purpose of sharing risk or financing. It occurs where one participant typically runs the entire operation, with the others contributing only funding and input on strategy-level decisions.

From the above, joint venture contracts have proved to be the most advantageous for the efficient operation especially in the Nigerian petroleum industry. Finally, joint ventures have also provided sustainable development through contribution to environmental, social and economic sustainability in Nigeria. 


\section{Operations and Management Contracts}

Under this arrangement, the public sector basically outsources the provision of services which were hitherto provided by it to the private sector. The payment for services is made directly to the private partner by the public partner, rather than through revenue collected directly from the end users, like in other PPP arrangements.

\section{Concessions}

Under a typical concession, the public sector grants (concessions) the private sector (concessionaire) a right to deliver certain services in certain areas for a fee paid by the concessionaire for those rights. The private sector operator is responsible for operation, maintenance and even rehabilitation of the asset including any capital required for upgrade and expansion even though ownership of the asset remains with the government throughout the duration of the concession period. The public sector sets performance standards and ensures that they are met thereby being in effect regulators of the price and the quality of services delivered. In the Nigeria oil and gas sector, concessions have been in practice from the colonial period till date. During the colonial period, Nigeria practiced the traditional concessions which proved to be disadvantageous to the host nation. Currently, there are modern concessions that run in form of oil exploration license, oil prospecting license and oil mining lease. In these concessions, Nigeria issues licenses to the private multinational companies and also acts as regulators for prices and quality of services delivered by the multinationals. As the de jure owners of the crude oil, Nigeria through its national oil company, regulates the activities of the private oil companies.

\section{The Legal and Institutional Framework for PPPs in Nigeria}

Some of the laws that constitute the legislative framework for PPP in Nigeria are:

a. Public-Private-Partnership and Road Infrastructure Development Order No. 007 of 2019

The Federal Government of Nigeria ${ }^{42}$ in furtherance of its commitment to infrastructure development issued the Companies Income Tax (Road Infrastructure Development and Refurbishment Investment Tax Credit Scheme) Order, $2019^{43}$ which was made pursuant to the executive powers of the Federation, as vested in the President. ${ }^{44}$ The Order established the Road Infrastructure Development and Refurbishment Investment Tax Credit Scheme as a

42 January 25, 2019.

43 Otherwise referred to as the Presidential Executive Order No. 007 of 2019 ("EO7" or the "Order").

44 By the Constitution of the Federal Republic of Nigeria, 1999 (as amended) and section 23(2) of the Companies Income Tax Act ("CITA" - Cap C21, Laws of the Federation of Nigeria, 2004). 
Public-Private-Partnership ("PPP") intervention in the delivery of good roads across the length and breadth of the Nigeria.

Pursuant to the EO7, private companies will be able to finance the construction or refurbishment of federal roads designated as "Eligible Roads" under the Scheme and recoup their investments by utilizing the approved total costs expended on the particular Eligible Roads, as a credit against the annual Companies Income Tax payable by such private companies in the corresponding year of assessment. The value of the credit due to a private sector partner, known as the Road Infrastructure Tax Credit ("Tax Credit"), as calculated in accordance with the terms of the Scheme, will be reflected on the Road Infrastructure Tax Credit Certificate ("Tax Credit Certificate") to be issued by the Federal Inland Revenue Service in line with the conditions stipulated in the Order.

In specific terms, the Scheme, which has duration of ten (10) years from the date of commencement of the EO7, is set up to: enable the FGN leverage on private sector funding for the construction or refurbishment of Eligible Road infrastructure projects in Nigeria; focus on the development of Eligible Road infrastructure projects in an efficient and effective manner that creates value for money through private sector discipline; and guarantee Participants in the scheme timely and full recovery of funds provided for the construction or refurbishment of eligible road infrastructure projects in the manner prescribed in the EO7. ${ }^{45}$

\section{b. The Public Procurement Act 2007}

The Procurement Act applies to procurement of goods and services carried out by the Federal Government of Nigeria, any public body engaged in procurement and all entities which derive at least $35 \%$ of the funds appropriated or proposed to be appropriated for any type of procurement from the Federation share of the Consolidated Revenue Fund. ${ }^{46}$ The Act does not apply to procurements carried out by the constituent states of the Federation. ${ }^{47}$

The Procurement Act does not expressly mention procurements done under PPPs like concessions and so it is believed that it only applies to traditional procurement and not to procurements done as PPPs. ${ }^{48}$ It is based on this that the Infrastructure Concession Regulatory Commission (ICRC) has stipulated some guidelines under the National PPP Policy for the PPP procurements. ${ }^{49}$

45 Toyin and Oluwatabo, note 30.

46 S. 15 of the Procurement Act, No.14 2007.

47 Ibid.

48 This assertion has been severely challenged by the Bureau of Public Procurement in relation to the Management Contract granted Manitoba Hydro of Canada to operate the transmission network by BPE.

49 Part 1 of the Supplementary Notes to the National Policy on Public Private Partnership (PPP). 
c. The Fiscal Responsibility Act 2007

The Fiscal Responsibility Act promotes the prudent management of the country's resources by ensuring greater accountability and transparency in fiscal operations and also by imposing limits on the country's spending and borrowing. The Act establishes the Fiscal Responsibility Commission to ensure that the objectives of the Act are met. ${ }^{50}$ From the foregoing, it is apparent that there ought to be coordination between the FRC, which is the primary body charged with PPP transactions in Nigeria and the Fiscal Responsibility Commission. If there is any kind of Government borrowing or spending on infrastructure, which is likely in PPP transactions, then the Fiscal Responsibility Commission ought to sanction it.

\section{d. The Infrastructure Concession Regulatory Commission Act 2005}

The Infrastructure Concession Regulatory Commission Act (the ICRC Act), which was enacted in 2005, provides the primary legal framework for Private Sector Participation in Infrastructure Development in Nigeria. The ICRC Act is divided into two parts: The first part vests government ministries and other agencies with power to enter into contracts with, or grant concessions to the private sector for the financing, construction, operation and maintenance of any viable infrastructure. ${ }^{51}$

The second part establishes the Infrastructure Concession Regulatory Commission (the ICRC), which is managed by a 12-member board that includes a part time chairman, the Attorney General of the Federation, the Governor of the Central Bank and a person from each of the six geopolitical zones of the country. The main function of the Commission is to take custody of every concession agreement or contract entered into by the Government Ministry or Agency, and monitor compliance with the CRC Act and the efficient execution of any such Concession Agreements. ${ }^{52}$

\section{e. The Debt Management Office Act 2003}

The Debt Management Act $^{53}$ established the Debt Management Office to prepare and implement a plan for the efficient management of Nigeria's external and domestic debt obligations and set guidelines for managing the country's risk and currency exposure with respect to all loans. ${ }^{54}$ PPP transactions will obviously require the Government of Nigeria to borrow both externally and internally as well as issue guarantees and therefore the Debt Management Office will necessarily be involved. However, there is nothing in any of the existing

\section{Ibid S. 6.}

51 Section 1 of the Act.

52 Sections 14, 15, 16 and 17 of the Act.

53 Debt Management Office Establishment, (etc.) Act No. 18 of 2003.

54 Ibid 5.4 . 
laws regulating PPPs that takes this fact into consideration and therefore potential investors are likely to be stranded.

\section{f. The Public Enterprises (Privatization and Commercialization) Act $1999^{55}$}

The Privatization Act provides the legal framework for the privatization and commercialization of various public assets in Nigeria. It also creates the National Council of Privatization (NCP) as the apex body charged with the responsibility of setting and administering the Federal Government's policies and objectives on privatization and approving transactions. The Act also established the Bureau of Public Enterprises (BPE) to function as the secretariat of the NCP and carry out the actual day-to-day privatization activities.

\section{g. The National Planning Commission Act $1993^{56}$}

The National Planning Commission was established by Act No.12 of 1992 and later amended by Act No. 71 of 1993 . The major function of the Act as it relates to infrastructure development is in relation to designing, coordinating and monitoring the implementation of the Nation's infrastructure master plan. It is therefore necessary that the CRC will need to first ensure that any projects ear marked for PPP is included in the nation's master plan designed by the National Planning Commission and also ensure that its activities are in concordance with that of the National Planning Commission. There is therefore a need for the PPP legislations to recognize this synergy.

\section{h. Utilities Charges Commission Act 1992}

Utilities Charges Commission Act 1992 established the Utilities Charges Commission that regulates tariff charged by public utilities in Nigeria. The implication of this is that the approval of the Commission may be required in fixing the tariffs between the private investor (concessionaire) and the Government. Like the law discussed above, the ICRCA does not contain a saving clause nor does it make a reference to the Utilities Charges Commission Act.

\section{i. Highways Act 1971}

The Highways Act ${ }^{57}$ empowers the Minister of Transport to construct and operate toll gates and collect tolls on the Federal Highways. What this means is that in concessions of federal roads that require tolling, the authority lies with the Minister in charge. Unfortunately, the

55 Privatization Act.

56 National Planning Commission Act CAP N66 Laws of the Federation of Nigeria 2004.

57 Section 2 Highways Act. 
main infrastructure legislation, the ICRCA, does not contain a saving provision with regard to this piece of legislation, nor does it make a reference to the Highways Act.

\section{Challenges of Public-Private-Partnership (PPP) in Nigeria}

The challenges of Public-Private-Partnership (PPP) in Nigeria are as follows, Inadequate knowledge, skills and capacity by participants both in public and the private sectors; poor evaluation, monitoring and due diligence by government; non-competitive bidding; signing of contract with no design and evidence of financing; difficulty in accessing credit facility from banks both locally and internationally; land acquisition problem; failure of risk allocations between the government and the concessionaire; and politicization of the concession. ${ }^{58}$ Other inherent challenges include partners' little confidence in each other, thus providing little or no basis for a lasting relationship, lack of clarity about project objectives and working methods, conflicting interests of the public and private sectors and lack of clarity about the allocation of responsibilities, reward, risks and resources

\section{Recommendations}

In Nigeria, as federal and state government began to explore more private sector resources in the delivery and operation of public facilities through PPPs. The paper suggests some strategies needed to be carried-out by government to encourage the private investors and to enhance PPP infrastructure project implementations. Suggested strategies emanate from the main identified challenges of Nigerian PPP practice. These include: i.Development of an innovative financing model for PPP projects in order to attract private investors ii. Establishment of pertinent PPP laws, regulations and guidelines in the development of efficient frameworks for best PPP practices. iii. Organize continuous training, workshops and conferences for public sector employees in Infrastructure Concession Regulatory Commission (ICRC), Ministries, Departments, and Agencies (MDAs), Bureau of Public Enterprises (BPE), Bureau of Public Procurement (BPP) and National Planning Commission (NPC) in terms of planning, this includes, project appraisal, procurement, contract and project management. iv. Public enlightenment, the stakeholders must inform, involve and include the public at very early stage of PPP cycle because of cultural behaviors' of Nigerians.

\section{Conclusion}

This paper has looked at the various definitions of PPP. Also the different types of PPPs were discussed, with a complete examination of the different meanings of the various acronyms that represent the diverse but similar financing options that characterize the concept. The paper took a critical look at the legal framework that underlies procurement of infra- 
structure and the engagement of private sector capital in infrastructure provision, maintenance and financing in Nigeria. The legal framework necessarily includes the related regulatory and industry specific legislation and the regulatory mechanism as a whole. The paper discovered that there are multiplicity of function by the various bodies regulating PPP and call for a synergy and proper delineation of roles by such bodies. The legal infrastructure which underpins the PPP framework in Nigeria is inadequate and the inadequacy of the legal and regulatory environment is partly responsible for the lack of enthusiasm for engagement on the part of the private sector especially foreign investors in the nation's public infrastructure assets and service delivery and the overall failure of the PPP mechanism in attracting the required private investment into infrastructure sector. Laws and contracts regulate the operations in Public-Private-Partnership (PPP) as such contracts must be drafted professionally to accommodate every conceivable circumstance with a view to benefit the public interest and ensure the increase of passionate zeal for private investment in Nigeria. The paper recommends that government must fundamentally improve their systems for dealing with the private sector to realize the efficiency and effectiveness gains that these partnerships promise

\section{BIBLIOGRAPHY}

Asian Development Bank,

$<$ http://www.a ec.org.au/docs/ADB\%20Public\%20Private\%20Partnership\%20Handbook pdf $>$ (Last accessed $2^{\text {nd }}$ July, 2019).

Augustine E.A. An appraisal for of the framework for Public Private Partnership in South Africa; European Journal of Procurement and Public Partnership Law Review (2018); Vol.13, No.3, p1.

Canadian council for Public- Private Partnership, http://www.pcouncil.ca/resources/about-Do/definitio ns.html (Last accessed on $17^{\text {th }}$ June, 2019).

Companies Income Tax Act ("CITA" - Cap C21, Laws of the Federation of Nigeria, 2004).

Conference on Infrastructure Development in Nigeria Report of the Nigerian Economic Summit Group International PPP and infrastructure development in Nigeria (2004) 1.

Constitution of the Federal Republic of Nigeria, 1999 (as amended) 2011.

Debt Management Office Establishment, (etc.) Act No. 18 of 2003.

Highways Act 1971.

International Monetary Fund, http//www.imf.org/external/n/fad /20041r1fo/eng/031204.pdf (Last accessed on $23^{\text {rd }}$ June, 2019).

International Monetary Fund, Public-Private Partnerships, Government Guarantees and Fiscal Risk, prepared by IMF Staff team, Washington D.C. international Monetary Fund 2006.

Investments in telecommunications industry grew from US million in 2000 to US billion in 2010. See Ahmed PPP for infrastructure development: The Nigerian experience (2011)

Jose L. N. and Jose A. M. 'Public Private Partnerships and Regional Productivity in the United Kingdom,' (online) at: http://www.reser.net/file/75439/ (Accessed 2 $2^{\text {nd }} J u l y, 2019$ ).

Malaysian Public Private Guidelines (2009) PPP Unit, Prime Ministers Department Putrajaya. 
National Planning Commission Act CAP N66 Laws of the Federation of Nigeria 2004

National Policy on Public Private Partnership (PPP).

Ndukwe, C., and Nwuzor, C., PPP for Effective and Efficient Services Delivery in Nigeria; A study of Ebonyi State Public Policy and Administrative Research. Vol. 6. No 5. 2016

Organisation for Economic co-operation and Development, http://www.ncprDo.org/howpart/index.sht ml\#define (Accessed on June 17, 2019)

Parliament of Australia, http://www.aph,gov.au/Iibra/ubs/rJ2002-Q3/03rr01.htm\#whatarppp (Last accessed on $23^{\text {rd }}$ June, 2019)

PPIAF, <http://www.ppiaf.org/ppiaf/sites/ppiaf.org/files/publicaton/WB\%20-\%20PP\%20Units\%20200 7.pdf (Last accessed $2^{\text {nd }}$ July, 2019).

Presidential Executive Order No. 007 of 2019.

Privatization Act, 2004.

Procurement Act, No.14 2007.

Project Appraisal Document. Others are: the Niger Delta region; food security; human capital; land tenure changes and home ownership; national security; and wealth creation.

Solomon, O.B., et-all in Challenges in Implementing Public Private Partnership strategy For Infrastructure Delivery in Nigeria. Faculty of Engineering and Environment, North Umbria University, Newcastle upon Tyne, NE1 8ST, UK http://www.nrl.northumbria.ac.uk/17191/3/babatunde_et_al_ ppp_conference_paper_\%25281\%2529_\%281\%29.pdf (Last accessed on $15^{\text {th }}$ July, 2019).

Takim, R. et all, A value for Money Assessment Method for Public Private Partnership: A Lesson from Malaysian Approach, International conference on Economics and Finance Research Singapore IPEDR, Vol. 14 http://www.ipedr.com/vol4/101-F10145.Pdf (Last accessed on 28 ${ }^{\text {th }}$ June, 2019).

The Infrastructure Concession Regulatory Commission (ICRC) National Policy on PPP (2009) 1012.

The World Bank (2011) Project appraisal document 6.

Toyin B. and Oluwatoba O. Nigeria: Public-Private-Partnership And Road Infrastructure Development In Nigeria: Understanding the Presidential Executive Order No. 007 Of 2019

World Bank Found, <http://ppp.worldbank.org/public-private- partnership/agreements/concessions-bot s-dbos $>$ (last accessed on 27th June, 2019)

Yescombe, E.R. Public-Private Partnerships: Principles of Policy and Finance, (Massachusetts: 2007) p 9. 